\title{
An Interesting Case of Basal Cell Carcinoma of the Face in Xeroderma Pigmentosum- Excision and Single Pedicle Advancement Flap
}

\author{
Authors \\ Dr Audipudi Venkata Ajit ${ }^{1}$, Dr Arun Narindar ${ }^{2}$, Dr RNM Francis ${ }^{3}$ \\ Department of General Surgery, Sree Balaji Medical College Hospital \\ Bharath University, Chennai, Tamilnadu, India \\ Email:ajit1a@gmail.com
}

\begin{abstract}
Xeroderma pigmentosum $(X P)$ is an autosomal recessive disorder characterized by extreme sensitivity to ultraviolet radiation and more than a 1,000-fold increase in the risk of cutaneous malignancy, basal cell carcinoma being the most common followed by squamous cell carcinoma and melanoma. It is a highly disfiguring disease with multiple recurring lesions requiring multiple surgical treatments. The need for cosmetically appropriate surgeries is of utmost importance in these patients. The paper describes the case of a 31 year old Indian male, diagnosed with Xeroderma pigmentosa, who presented with basal cell carcinoma of the left cheek and was treated with wide local excision and a single pedicle advancement flap with a good cosmetic outcome and margin clearance.

Keywords: Xeroderma Pigmentosum, Basal Cell Carcinoma, Advancement Flap
\end{abstract}

\section{Introduction}

Xeroderma pigmentosum (XP) is an autosomal recessive disorder characterized by hyper sensitivity to ultraviolet radiation and more than a thousand fold increase in the risk of cutaneous malignancy, basal cell carcinoma being the most common followed by squamous cell carcinoma and melanoma. ${ }^{[1][2][3]}$ Basal cell carcinoma usually occurs on areas of the skin that have been in the sun, most often the nose ${ }^{[4]}$. Since long time the conventional treatment option is surgical excision with free safety margins. A narrow free surgical margin would imply a higher recurrence rate. ${ }^{[5]}$

A proper surgical excision would leave a soft tissue defect which would pose to be a cosmetic issue. This coupled with the patients expectation for an improved quality of life post surgery would warranty cosmetically sound high quality reconstruction. ${ }^{[6]}$ Primary closure and local flaps give a better cosmetic and functional outcome as compared to free flaps or skin grafts. ${ }^{[7]}$ A single pedicle advancement skin flap is a flap that is mobilized by undermining and advancement into a defect without altering the plane of the pedicle. This technique can be considered for use in repair when there is skin available on only one side of a wound. Basic square or rectangular defects lend themselves well to single pedicle advancement flaps ${ }^{[8]}$ This paper discuses the use of single pedicle advancement flap in covering the defect post excision of the basal cell carcinoma of face. 


\section{Case Report}

We present a case of a 31year old male patient who was a known case of Xeroderma pigmentosum presented with a swelling over the left side of the cheek close to the alar crease which was insidious and progressive for a duration of 6 months.

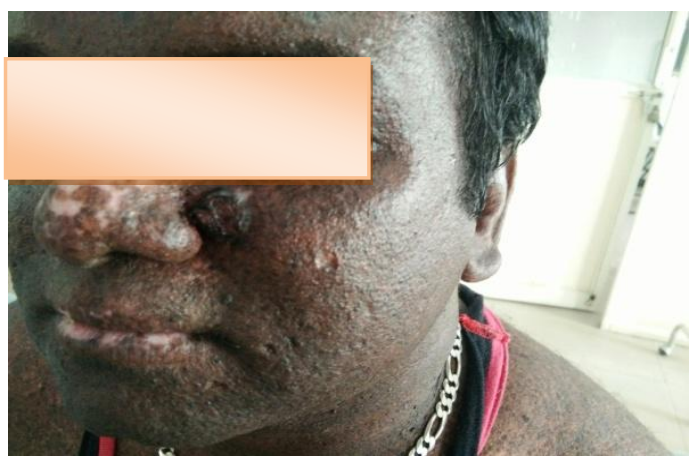

Fig. 1Basal Cell Carcinoma left cheek

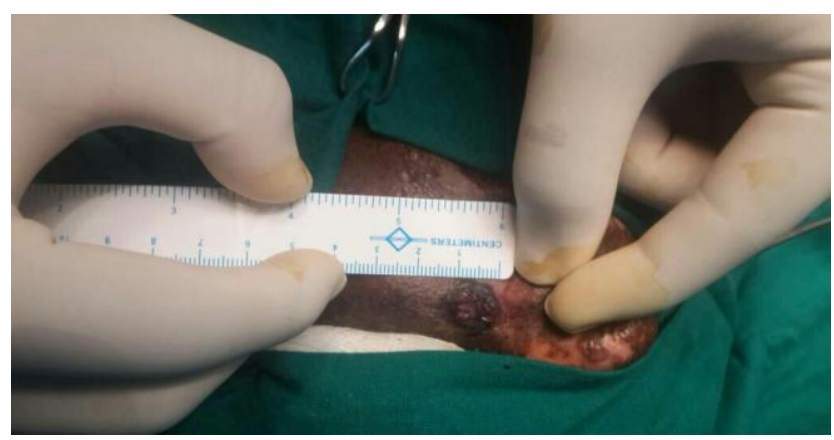

Fig.2 Assessment for margins and reconstruction

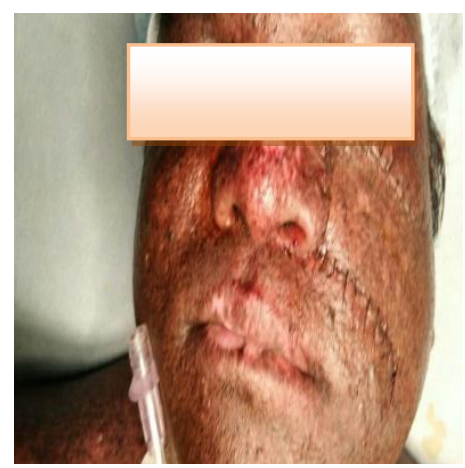

Fig 3 Post operative Image

There was no history of pain, discharge, bleeding, itching or crusting There was no history of any other complains. The patient was moderately built and well nourished with mosaic skin appearance and cloudy cornea.

Local examination revealed a $1 \times 1 \times 0.5 \mathrm{~cm}$ hyper pigmented lesion over the left side of the cheek (fig.1) close to the alar crease which was non tender and firm in consistency arising from the skin. There were no other swellings elsewhere over the body. Systemic examination was normal The patient underwent wide local excision of the lesion with a $4 \mathrm{~mm}$ margin under local anaesthesia. The defect post excision was closed using a single pedicle advancement flap. Two parallel divergent lines were drawn on the skin from the adjacent corners of the defect. The length of the flap was measured to be $2 \mathrm{~mm}$ more than the length of the wound. Incisions were made along the drawn lines and the skin undermined to include the subcutaneous tissue. The flap was advanced over the wound and tension free interrupted sutures were applied with 5-0 nylon. Post operatively the patient developed facial edema which subsided in the following three days. Suture removal was done after 7 days

Histopathological examination showed features suggestive of basal cell carcinoma with tumor negative margins

\section{Discussion}

In this case, the basal cell carcinoma was excised three dimensionally with tumour free margins and reconstruction. Appropriate margins for malignant tumors depend on the cancer type, tumor size, tumor irregularity, and time elapsed from onset. In cases of basal cell carcinoma, an appropriate excision margin would be 2 to $5 \mathrm{~mm}$ from the tumor, whereas in cases with a small-sized lesion of $<2 \mathrm{~cm}$ in diameter, it would be approximately 4 $\mathrm{mm}$. On the other hand, in cases with a lesion of $>2 \mathrm{~cm}$ in diameter or with a substantial delay after onset, the margin would be $1 \mathrm{~cm}$, and in recurrent cases, it would be $>1 \mathrm{~cm} \cdot{ }^{[5][6]}$. There is no clear criteria for the selection of a single type of reconstructive technique amongst many available. ${ }^{[9]}$ primary closure is the most common technique used to close soft tissue defects. For small and medium sized defects, local flaps would be a better choice ${ }^{[10]}$. Because flaps have the advantage of carrying their blood supply with them to maintain viability, they can be placed over less-than-optimal wound beds, including exposed bone or irradiated tissue. Advancement flaps can be used in patients with a good health 
status. Single pedicle advancement flaps are the simplest of local flaps. They provide an advantage of matching the color and texture of the excised skin. ${ }^{[8]}$

\section{Conclusions}

Single pedicle advancement flap is a feasible option for the treatment of small to medium size facial defects, its advantage being a relatively simple technique with better cosmetic outcome.

\section{Acknowledgement}

The heading of the Acknowledgment section and the References section must not be numbered.

\section{References}

1. Kraemer $\mathrm{KH}$, Lee MM, Scotto J: Xeroderma pigmentosum. Cutaneous, ocular, and neurologic abnormalities in 830 published cases. Arch Dermatol 1987;123:241-250.

2. Kraemer KH, Ruenger TM. Genome instability, DNA repair and cancer. In: Wolff K, Goldsmith LA, Katz SI, Gilchrest BA, Paller AS, Leffell DJ, editors. Fitzpatrick's Dermatology in General Medicine. Vol 7 ed. New York: McGraw Hill 2008; 977-86.

3. Ruenger TM, DiGiovanna JJ, Kraemer KH. Hereditary Diseases of genome instability and DNA repair. In: Wolff K, Goldsmith LA, Katz SI, Gilchrest BA, Paller AS, Leffell DJ, editors. Fitzpatrick's Dermatology in General Medicine. Vol 7 ed. New York: McGraw Hill 2008; 131125

4. https://www.ncbi.nlm.nih.gov/pubmedheal th/PMHT0024883/

5. Katz KH, Desciak EB, Maloney ME. The optimal application of surgical adhesive tape strips. Dermatologic surgery: official publication for American Society for Dermatologic Surgery[et al]. 1999;25(9):686-8. Epub 1999/09/22

6. Strauch B, Fox M. VY bipedicle flap for resurfacing the nasal supratip region.
Plastic and reconstructive surgery. 1989;83(5):899-903. Epub 1989/05/01

7. Kwon KH, Lee DG, Koo SH, Jo MS, Shin $\mathrm{H}$, Seul JH. Usefulness of $\mathrm{v}-\mathrm{y}$ advancement flap for defects after skin tumorexcision. Archives of plastic surgery 2012;39(6):619-25.Epub 2012/12/13

8. http://vet360.vetlink.co.za/wound-repairtechniwues-single-pedicle-advancementflaps/

9. Mosterd K, Krekels GA, Nieman FH, Ostertag JU, Essers BA, Dirksen CD, et al. Surgical excision versus Mohs' micrographic surgery for primary and recurrent basal-cell carcinoma of the face: a prospective randomised controlled trial with 5-years' follow-up. The lancet oncology. 2008;9(12):1149-56. Epub 2008/11/18

10. Pepper JP, Baker SR. Local flaps: cheek and lip reconstruction. JAMA facial plastic surgery.2013; 15(5) 374-82. Epub 2013/09/21 